\title{
The NMR Study and Antimicrobial Activity of Some Schiff Bases Derived From Sulphonamide Drug
}

\author{
Wasfi A. Al-Masoudi ${ }^{1^{*}}$, Harith Y. Mahmood ${ }^{1}$, Rasha M. Othman ${ }^{2}$ and Wasan M. Shaker ${ }^{2}$ \\ ${ }^{1}$ Department of Physiology and Chemistry, College of Veterinary, University of Basrah, Iraq \\ ${ }^{2}$ Department of Microbiology, College of Veterinary, University of Basrah, Iraq \\ *Corresponding author: almasoudi59@yahoo.com
}

\begin{abstract}
Some Schiff base compounds derived from sulfonamide drug were synthesized by reaction of 4aminobenzenesulfonamide with aromatic aldehydes (2-hydroxy-1-naphthaldehyde, 3,4-dihydroxybenzaldehyde and 2hydroxy benzaldehyde) in good yields. Characterization of synthesized compound was carried by elemental analysis, IR, ${ }^{1} \mathrm{H},{ }^{13} \mathrm{C}, \mathrm{HSQC}$ and HMBC- NMR spectroscopy. The synthesized compounds were screened for their antibacterial activity against Staphylococcus aureus, Streptococcus sp., Bacillus subtillus, Escherichia coli and Klebsiella pneumonia. Additionally, the compounds were tested for antifungicidal activity against Candida krusei, Candida tropicalis, Aspergillus fumigates and Aspergillus niger.
\end{abstract}

Key words: Sulfonamide, Schiff base, NMR, Antimicrobial activity, Aldehydes.

\section{Council for Innovative Research}

Peer Review Research Publishing System

Journal: Journal of Advances in Chemistry

Vol. 12, No. 2

editor@cirjac.com

www.ciriac.com 


\section{INTRODUCTION}

Sulphonamides were the first drugs found to act selectively and could be used systematically as preventive and the therapeutic agents against various diseases [1]. In medicine, the term "sulfonamide" is sometimes used as a synonym for sulfa drug, a derivative or variation of sulfanilamide. The first sulfonamide was discovered in 1932[2]. The condensation products of sulpha drugs with aldehydes and ketones are biologically active [3,4].

Schiff bases are used as pigments and dyes, catalysts, intermediates inorganic synthesis and as polymer stabilizers. A number of Schiff's base molecules show biological activities including antibacterial, antifungal, antidiabetic, antitumour, antiproliferative, anticancer, anti-corrosion and anti-inflammatory activities [5-8]. Sulfa Schiff bases have been subject to thorough studies where a wide diversity of these derivatives have been prepared and used in various biological and pharmacological fields [9-11]. The aim of present work is to synthesis of some Schiff base derived from sulphonamide (Scheme1) and study the biological activity theoretically (Molecular modiling and in vitro antimicrobial activity.

\section{EXPERIMANTAL}

\section{a- Physical mesurments}

Infrared spectra (IR) were recorded as $\mathrm{KBr}$ discs in the range of 4000-400 $\mathrm{cm}^{-1}$ using FT-IR spectrophotometer Shimadzu model IR. Affinity-1 at the department of Chemistry, College of Education for pure sciences, University of Basrah, Iraq. ${ }^{1} \mathrm{H}$, ${ }^{13} \mathrm{C}$, Roesy, HSQC and HMBC NMR spectra were measured on a Brucker at $600 \mathrm{MHz}$, with TMS as internal reference at Konstanz university, Germany. Microanalysis for carbon, hydrogen and nitrogen were carried out by a Perkin-Elmer 240B Elemental Analyzer. Melting points were measured by a Philip Harris melting point apparatus and uncorrected.

\section{b- Synthesis}

\section{General Synthesis of Schiff-bases5-7}

4-aminobenzenesulfonamide 1 (1.37, $2.00 \mathrm{mmol})$ and aromatic aldehydes (2-4) (2.1 mmol) were dissolved in absolute ethanol followed by addition of catalytic amount of glacial acetic acid dropwise and the mixture was heated under reflux for 4h. The reaction mixture was then cooled in an ice bath and the crude product thus obtained was collected by filtration, further purified by recrystallization from ethanol.

\section{4-\{[(2-hydroxynaphthalen-1-yl)methylidene]amino\}benzenesulfonamide 5}

Yield,82 \%, as a yellow solid, M.p. $=276-278^{0} \mathrm{C}, \mathrm{FT}-\mathrm{IR}\left(\mathrm{KBr}, \mathrm{v}, \mathrm{cm}^{-1}\right): 3420-3335(\mathrm{OH}, \mathrm{NH}), 3082-3063(\mathrm{CH}$-aromatic), $1622(\mathrm{C}=\mathrm{C}), 1602(\mathrm{C}=\mathrm{N})$. ${ }^{1} \mathrm{H}$ NMR $\left(600 \mathrm{MHz}, \mathrm{DMSO}-d_{6}, \delta, \mathrm{ppm}\right): 15.46(\mathrm{~s}, 1 \mathrm{H}, \mathrm{OH}), 9.69(\mathrm{~s}, 1 \mathrm{H}, \mathrm{CH}=\mathrm{N}), 8.41-7.01(\mathrm{~m}, 10 \mathrm{H}$, $\mathrm{Ar}-\mathrm{H}), 7.47(\mathrm{~s}, 2 \mathrm{H}, \mathrm{NH}) .{ }^{3} \mathrm{C} \mathrm{NMR}(600 \mathrm{MHz}$, DMSO-d $, \delta, \mathrm{dpm}): 171.5(\mathrm{C}-\mathrm{O}), 156.9(\mathrm{C}=\mathrm{N}), 147.2-109.3$ (C-Ar).

Anal. for $\mathrm{C}_{17} \mathrm{H}_{14} \mathrm{~N}_{2} \mathrm{O}_{3} \mathrm{~S}$ (M.wt 326.3):Calc.C,62.51; H, 4.29; N, 8.58; Found: C, 62.24; H, 3.97; N, 8.31.

\section{4-[(3,4-dihydroxybenzylidene)amino]benzenesulfonamide 6}

Yield, $78 \%$ as a brown solid, M.p. $=136-138{ }^{\circ} \mathrm{C}, \mathrm{FT}-\mathrm{IR}\left(\mathrm{KBr}, \mathrm{v}, \mathrm{cm}^{-1}\right): 3417-3300(\mathrm{OH}, \mathrm{NH}), 3074-3052(\mathrm{CH}$-aromatic), $1610(\mathrm{C}=\mathrm{C}), 1598(\mathrm{C}=\mathrm{N}) .{ }^{1} \mathrm{H}$ NMR $\left(600 \mathrm{MHz}, \mathrm{DMSO}-d_{6}, \delta, \mathrm{ppm}\right): 9.71(\mathrm{~s}, 1 \mathrm{H}, \mathrm{CH}=\mathrm{N}), 8.41-6.59(\mathrm{~m}, 10 \mathrm{H}, \mathrm{Ar}-\mathrm{H}) .{ }^{13} \mathrm{C}$ $\operatorname{NMR}\left(600 \mathrm{MHz}\right.$, DMSO- $\left.d_{6}, \bar{\delta}, \mathrm{ppm}\right): 162.5(\mathrm{C}=\mathrm{N}), 155.3-116.0(\mathrm{C}-\mathrm{Ar})$.

Anal. for $\mathrm{C}_{13} \mathrm{H}_{12} \mathrm{~N}_{2} \mathrm{O}_{4} \mathrm{~S}($ M.wt 292.3):Calc. C, 53.36; H, 4.10; N, 9.59; Found: C, 52.98; H, 3.97; N, 9.31.

4-[(2-hydroxybenzylidene)amino]benzenesulfonamide 7

Yield,72\% as a yellow solid, M.p. $=222-224{ }^{0} \mathrm{C}, \mathrm{FT}-\mathrm{IR}\left(\mathrm{KBr}, \mathrm{v}, \mathrm{cm}-{ }^{1}\right): 3400-3325(\mathrm{OH}, \mathrm{NH}) 3080-3067(\mathrm{CH}-$ aromatic $)$, $1618(\mathrm{C}=\mathrm{C}), 1600(\mathrm{C}=\mathrm{N}) .{ }^{1} \mathrm{H}$ NMR $\left(600 \mathrm{MHz}\right.$, DMSO- $\left.d_{6}, \delta, \mathrm{ppm}\right): 8.97(\mathrm{~s}, 1 \mathrm{H}, \mathrm{CH}=\mathrm{N}), 8.52-7.01(\mathrm{~m}, 10 \mathrm{H}, \mathrm{Ar}-\mathrm{H}) .{ }^{13} \mathrm{C}$ $\operatorname{NMR}\left(600 \mathrm{MHz}, \mathrm{DMSO}-d_{6}, \delta, \mathrm{ppm}\right): 170.2(\mathrm{CH}=\mathrm{N}), 152.3-112.9(\mathrm{C}-\mathrm{Ar})$.

Anal. for $\mathrm{C}_{13} \mathrm{H}_{12} \mathrm{~N}_{2} \mathrm{O}_{3} \mathrm{~S}(\mathrm{M} . w t 276.3)$ :Calc. C,56.46; H, 4.34; N, 10.13; Found: C, 56.14; H, 3.97; N, 9.92.
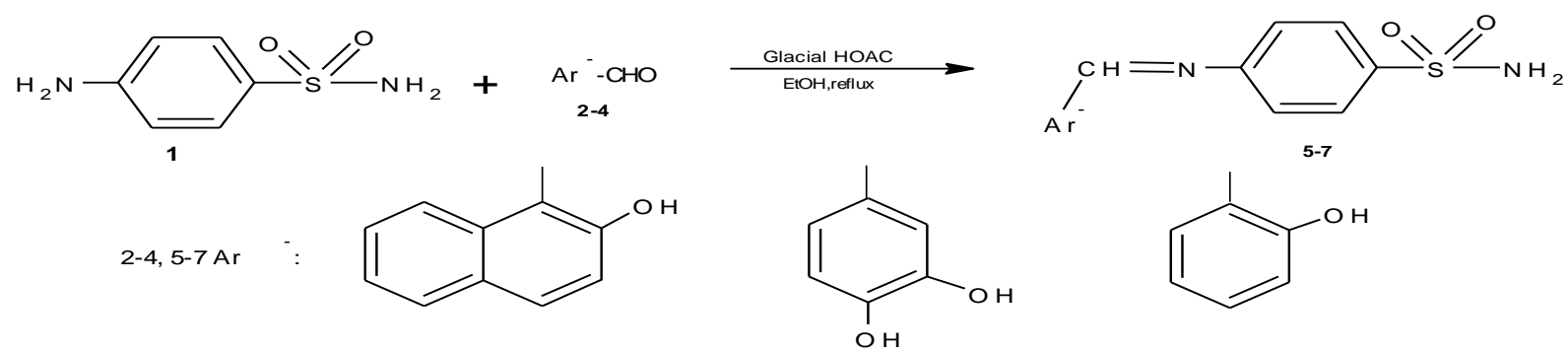

Scheme 1: Preparation of some Schiff-base of sulphonamide 


\section{c- Antimicrobial activity}

The synthesized compounds were screened in vitro for their antibacterial activity against:Staphylococcus aureus, Streptococcus sp., Bacillus subtillus, Escherichia coli and Klebsiella pneumonia. Additionally, the compounds were tested also for antifungal activity against Candida albicans, Candida tropicalis, Aspergillus fumigates and Aspergillus niger using the paper disc-agar diffusion technique on Muller Hinton agar and Sabouraud dextrose agaras a culture media for antibacterial activity and antifungal activity, respectively [12]. The test compounds were dissolved in DMSO solvent and recommended concentrations $(50,100$ and $200 \mu \mathrm{g} / \mathrm{mL})$ were used in the disc-agar diffusion technique. Antibiotic drug Ampicillin and Nystatin were used as control for bacteria and fungi, respectively. Petri plates containing $20 \mathrm{~mL}$ of Mueller Hinton Agar were used for all the bacteria tested. Fungistrains were cultivated in Sabouraud dextrose agar. Sterile Whatman no. 1 filter paper disks $(6 \mathrm{~mm}$ in diameter) impregnated with the solution in DMSO of the test were placed on the Petri plates. A paper disk impregnated with dimethyl sulfoxide (DMSO) was used as negative control. The plates were incubated for $24 \mathrm{~h}$ at $37{ }^{\circ} \mathrm{C}$ in the case of bacteria and $72 \mathrm{~h}$ that $27^{\circ} \mathrm{C}$ for fungi. The inhibition zone diameters were measured in millimeters. The bacteria and fungi were supplied from department of Microbiology, College of Veterinary Medicine, University of Basrah.

\section{RESULTS AND DISCUSSION}

\section{Chemistry}

Treatment of 4-aminobenzenesulfonamide1 with three aldehyde derivatives (2-hydroxy-naphthaldehyde 2, 3,4dihydroxybenzaldehyde 3 and 2-hydroxybenzaldehyde 4 in ethanol and catalytic by 3-4 drops of glacial acetic acid under reflux afforded the desired imine derivatives 5-7 in 82, 78 and $72 \%$ yields, respectively (Scheme 1). The structures of the synthesized compounds were assigned by the elemental analysis $(\mathrm{CHN}), \mathrm{IR}$ and ${ }^{1} \mathrm{H},{ }^{13} \mathrm{C}$ and $2 \mathrm{D}$ NMR. The IR spectra confirm the presence of the azomethine group $(-\mathrm{CH}=\mathrm{N})$ stretching with a sharp region for compounds 5-7 at 1602,1598 and $1600 \mathrm{~cm}^{-1}$, respectively. In addition, the bands at the region $1622-1610 \mathrm{~cm}^{-1}$ were assigned to the $\mathrm{C}=\mathrm{C}$ aromatic group. In the ${ }^{1} \mathrm{H}$ NMR spectra of compounds 5-7, the singlets at $\delta 9.69,9.71$ and $8.97 \mathrm{ppm}$ respectively, were assigned for the imine protons $(\mathrm{CH}=\mathrm{N})$. The multiplets at the regions $\delta 8.52-6.59 \mathrm{ppm}$ were attributed to the aromatic protons.

In the ${ }^{13} \mathrm{C}$ NMR spectra of compounds 5-7, the resonances at $\delta 155.3-109.3 \mathrm{ppm}$ were assigned for the aromatic carbon atoms (C-Ar). The spectra revealed the presence of $\mathrm{CH}=\mathrm{N}$ group around 156.9, 162.5 and 170.2 ppm, Figures 1-3 and $6,9,11$.

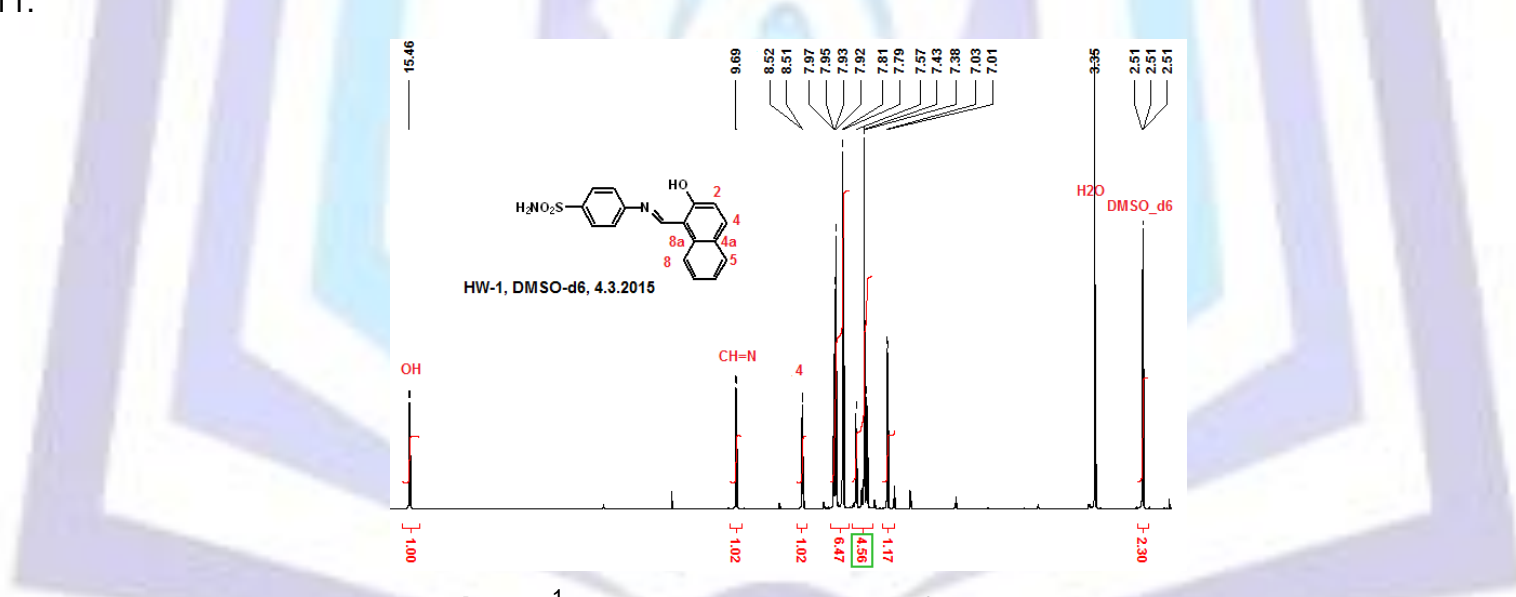

Fig. 1: ${ }^{1} \mathrm{H}$ NMR spectroscopy of compound 5

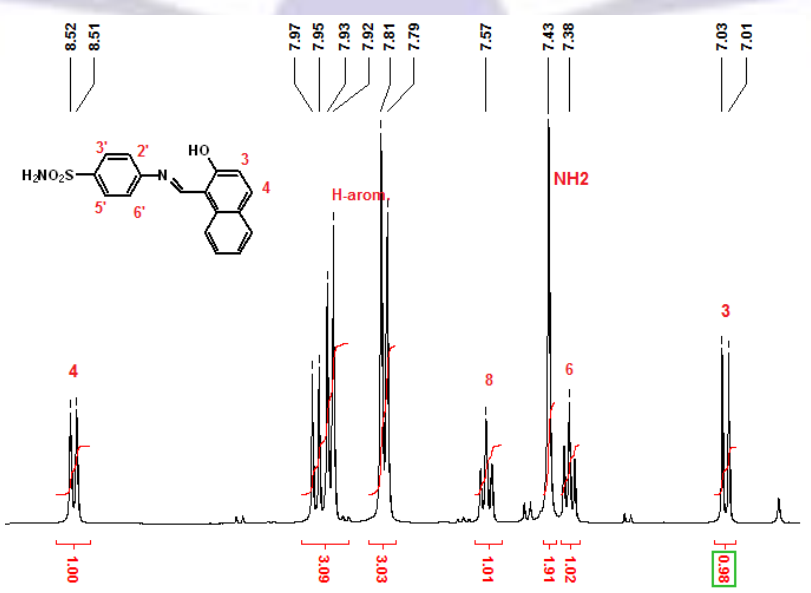

Fig. 2: ${ }^{1} \mathrm{H}$ NMR spectroscopy (expantion) of compound $\mathbf{5}$ 


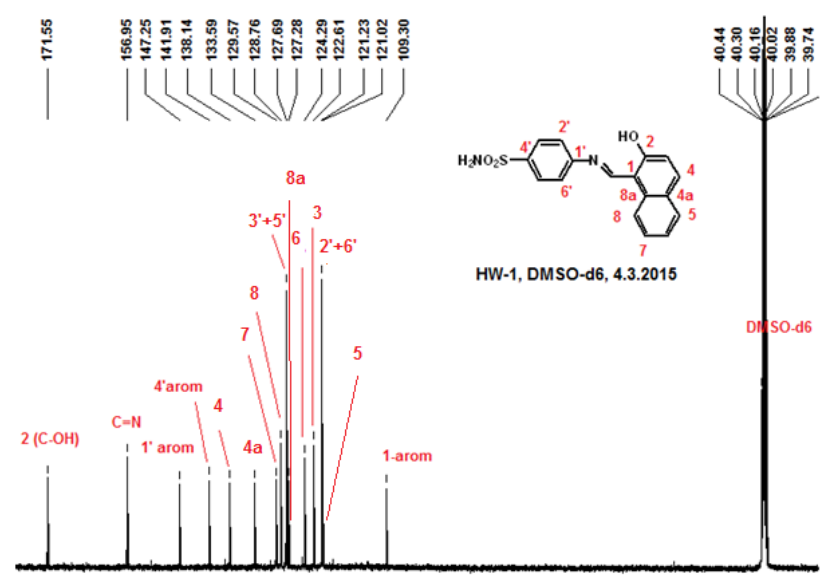

Fig. 3: ${ }^{13} \mathrm{C}$ NMR spectroscopy of compound 5

The ${ }^{1} \mathrm{H},{ }^{13} \mathrm{C}$ HSQC NMR spectrum of Schiff base 5 showed a cross peak at $\delta_{\mathrm{H}} / \delta_{\mathrm{C}}=9.70 / 156.9$ ppm due to azomethine group $(\mathrm{N}=\mathrm{CH})$, Thus, the correlation of protons and carbon in aromatic rings such as $\delta_{\mathrm{H}} / \delta_{\mathrm{C}}=8.52 / 121.0,7.95 / 138.0 \mathrm{ppm}$ and other positions can be assigned to the protons and carbon atoms of the aromatic ring, Table 1, Figure 4.

Table (1): HSQC data for compound 5

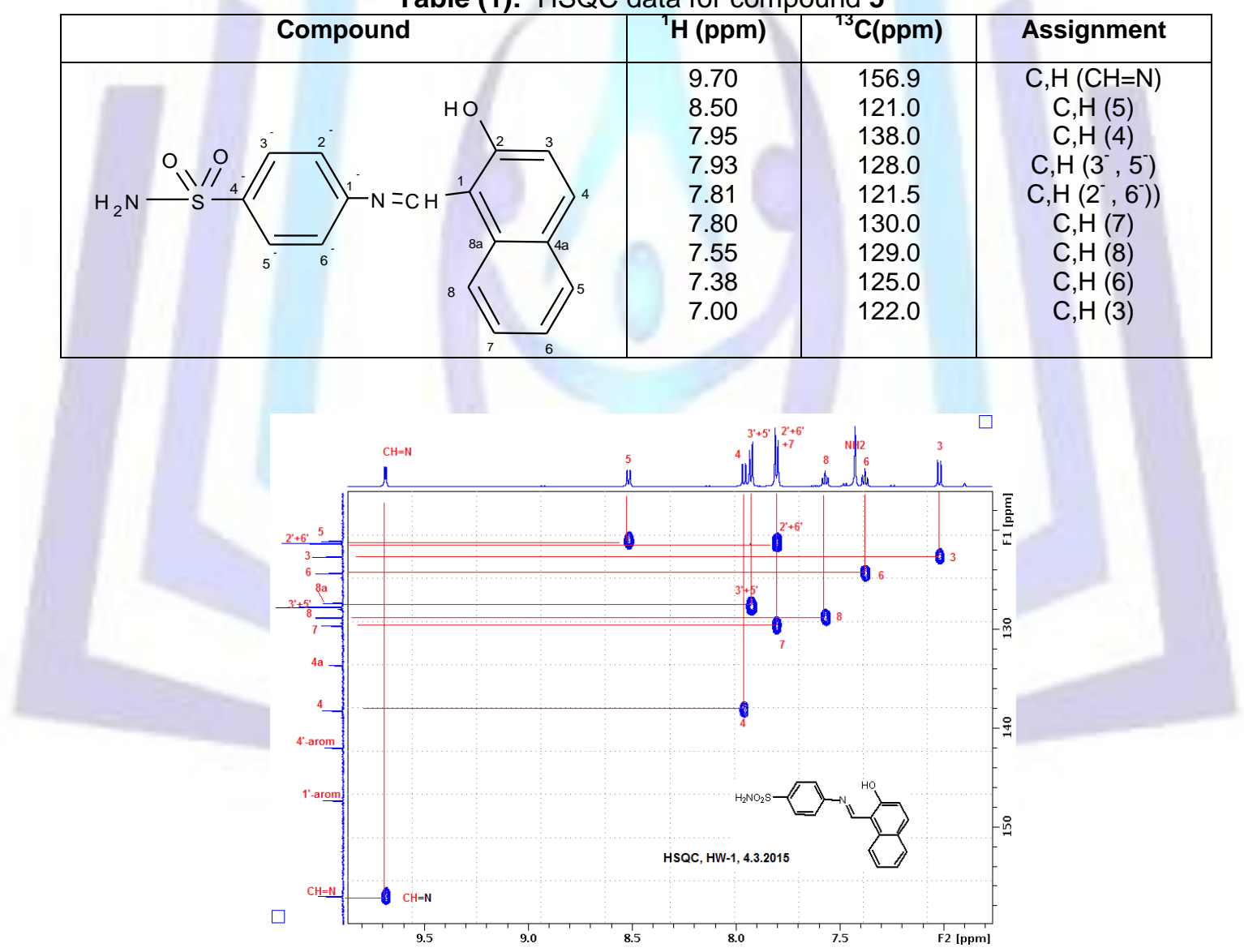

Fig. 4: HSQC- NMR spectroscopy of compound 5

The gradient-selected ${ }^{1} \mathrm{H},{ }^{13} \mathrm{C}, \mathrm{HMBC}$ NMR spectrum of compound $\mathbf{5}$ revealed two ${ }^{1,3} \mathrm{~J}, \mathrm{H}$. Thus, the imino proton $(\mathrm{CH}=\mathrm{N})$ at $\delta 9.70 \mathrm{ppm}$ showed two ${ }^{1,3} \mathrm{~J}_{\mathrm{C}, \mathrm{H}}$ correlations: first one with $\mathrm{C}-1$ of the naphthyl ring at $\delta 160.3 \mathrm{ppm}$, the second correlation with the aromatic carbon atom C-6' at $\delta 109.3 \mathrm{ppm}$ and the last one with the aromatic carbon atom C-1' at $\delta 147.2 \mathrm{ppm}$. Othercorrelations between protons and carbon atoms can be assigned in Figure 5.

The HSQC and HMBC-NMR Spectra of compounds 6 and 7 were supported the structures of synthesized compounds, Figures $7,8,10$ and11. 


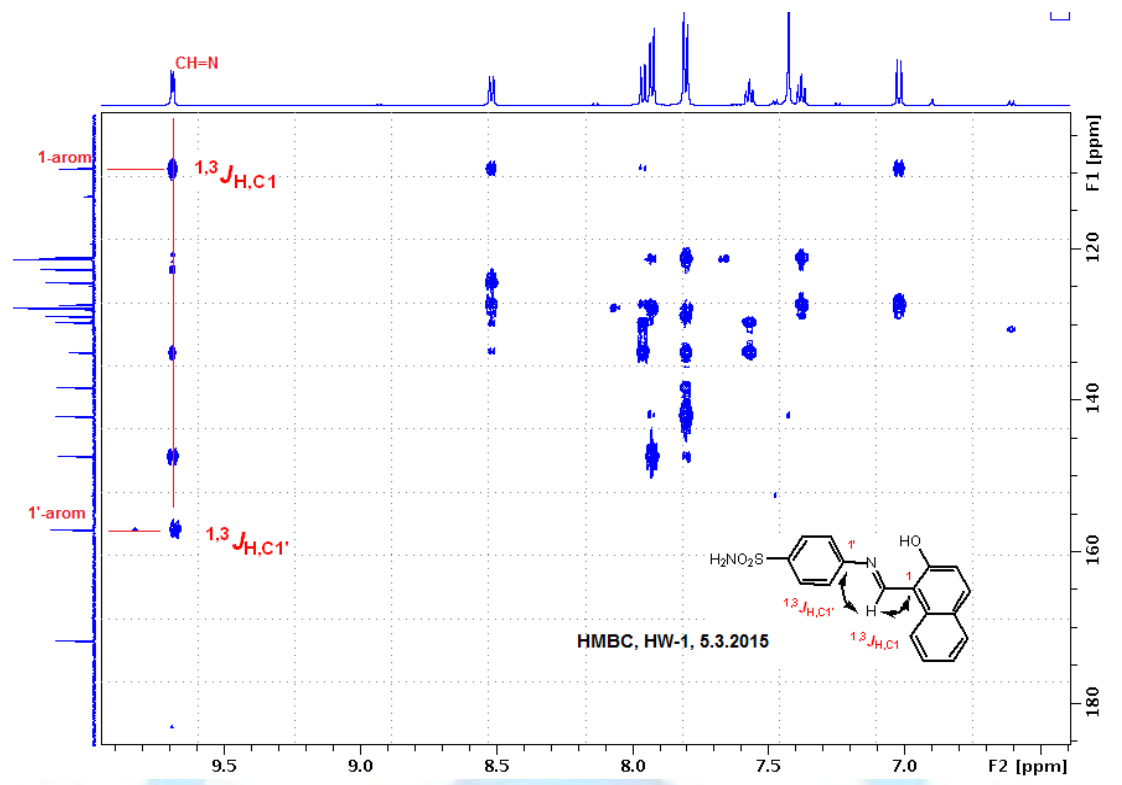

Fig. 5: HMBC- NMR spectroscopy of compound $\mathbf{5}$

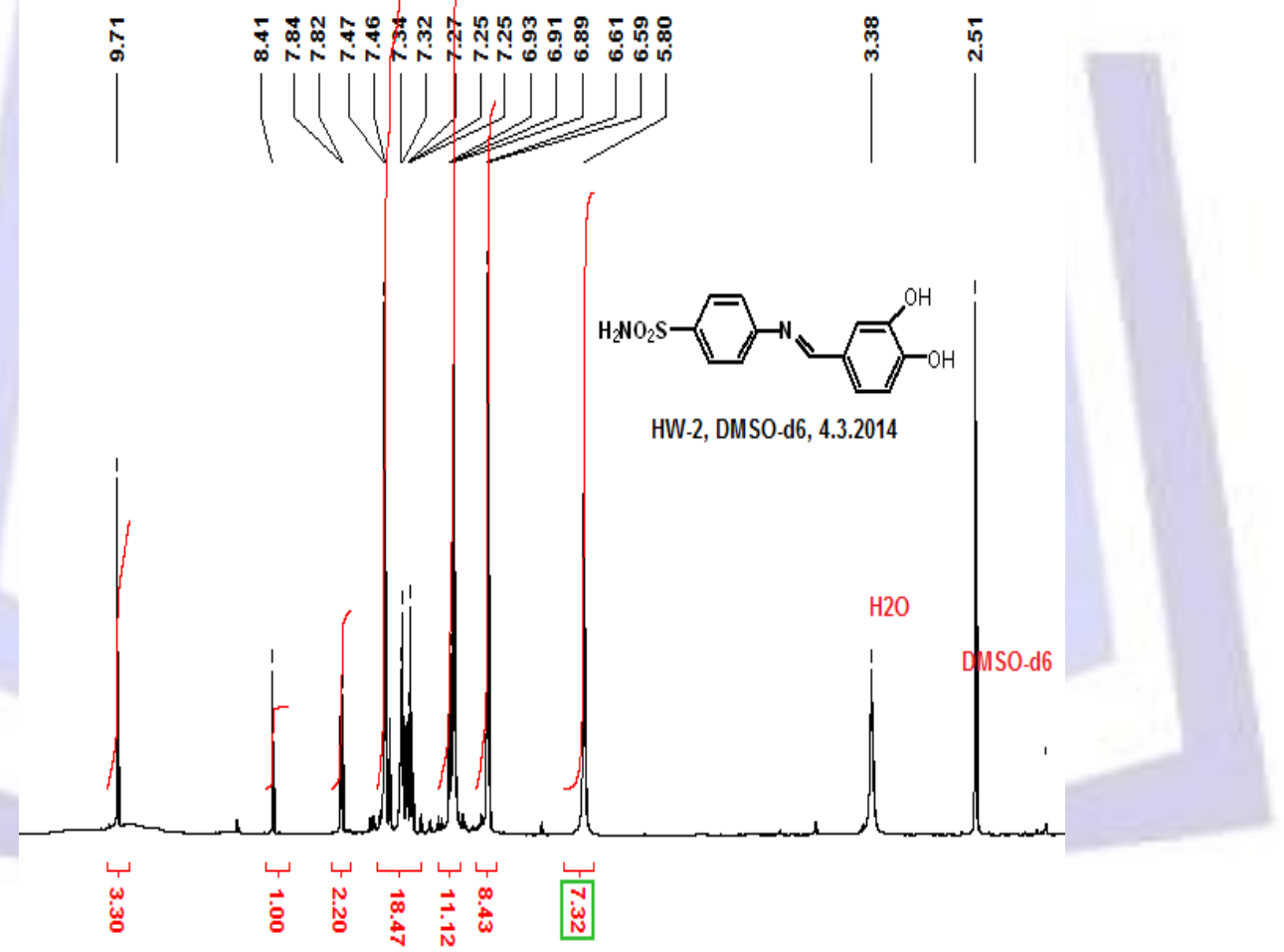

Fig. 6: ${ }^{1} \mathrm{H}$ NMR spectroscopy of compound 6 


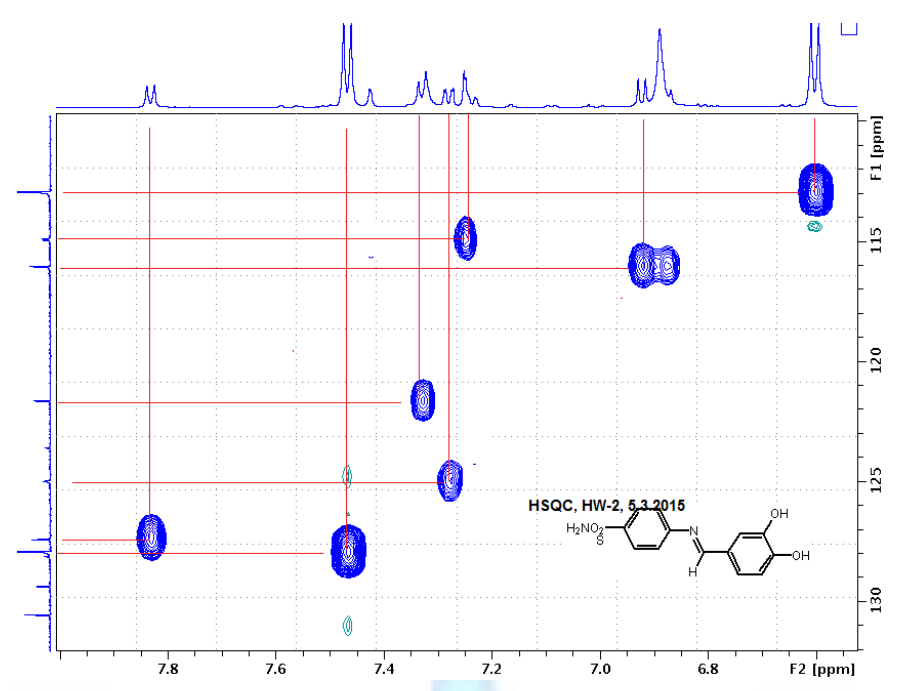

Fig. 7: HSQC- NMR spectroscopy of compound 2

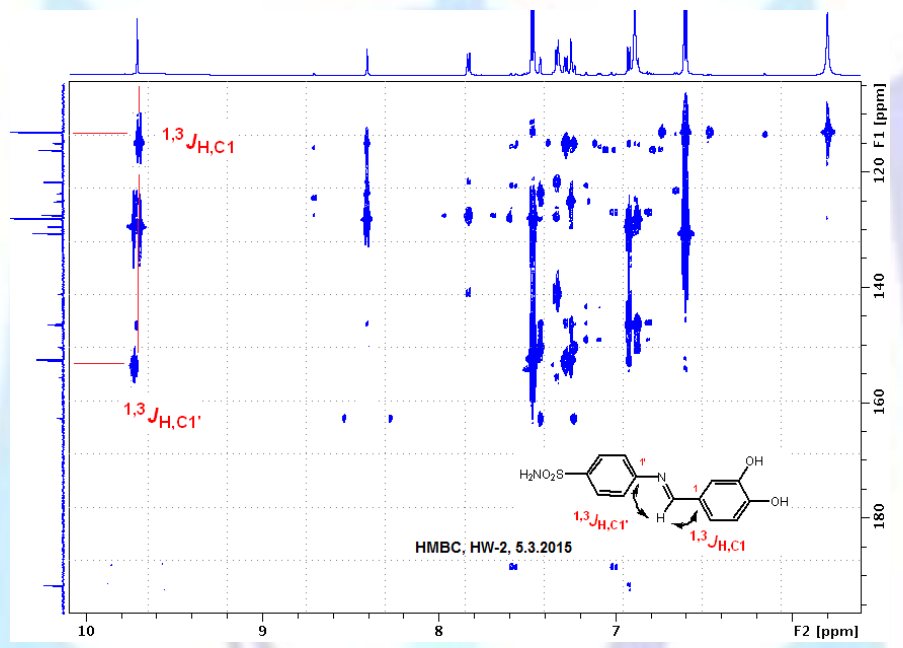

Fig. 8: HMBC- NMR spectroscopy of compound 2 |

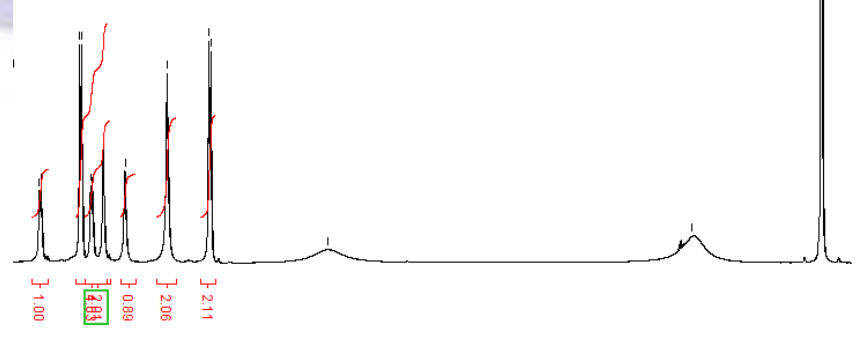

Fig. 9: ${ }^{1} \mathrm{H}$ NMR spectroscopy of compound 3 


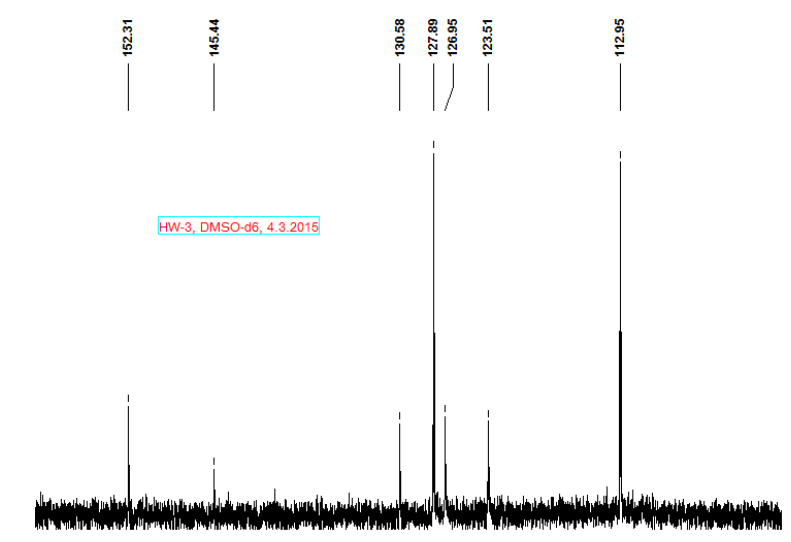

Fig. 10: ${ }^{13} \mathrm{C}$ NMR spectroscopy of compound 3

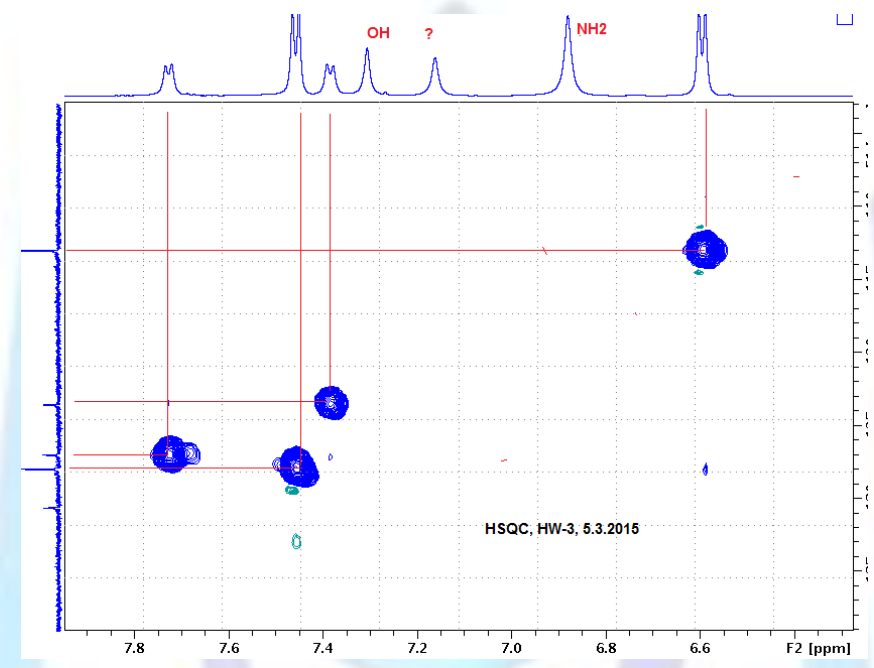

Fig. 11: HSQC- NMR spectroscopy of compound 3

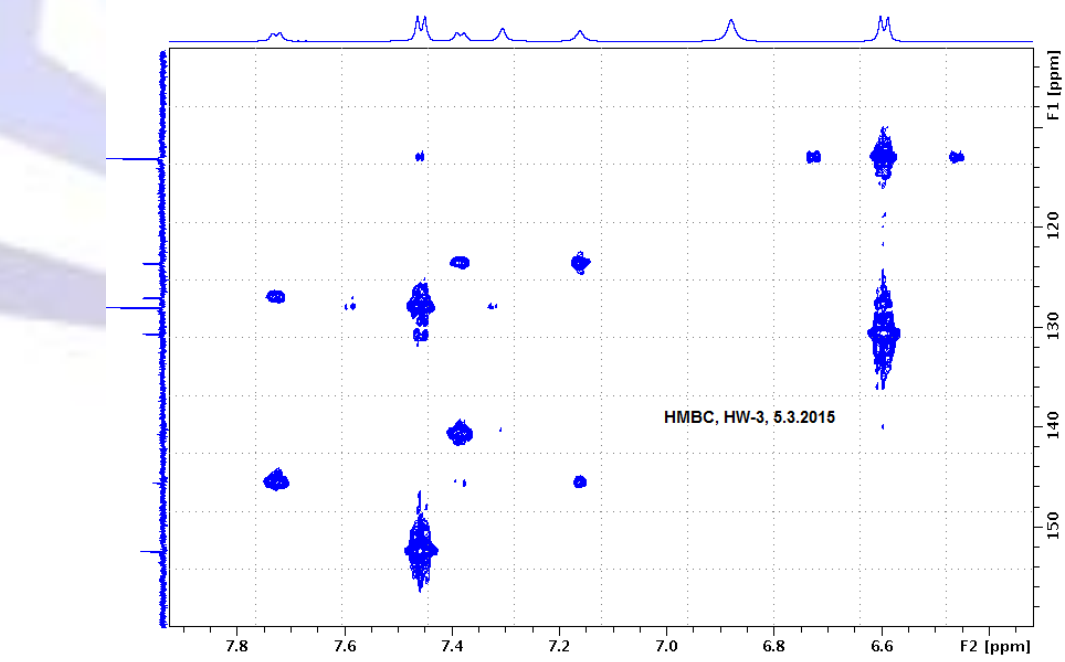

Fig. 12: HMBC- NMR spectroscopy of compound 3

\section{Antimicrobial activity}

The studied compounds have been evaluated in vitro for their antibacterial and antifungal activities, using the paper discagar diffusion technique [12] by measuring the inhibition zone in $\mathrm{mm}$. Antibiotic drug ampicillin and Nystatin were used as control for bacteria and fungi, respectively. The antibacterial activity of the synthesized compounds were tested against three Gram positive bacteria (Staphylococcus aureus,Streptococcus sp., Bacillus subtillus) and two Gram negative bacteria (Escherichia coli and Klebsiella pneumonia) at a concentration of 50, 100 and $200 \mu \mathrm{g} / \mathrm{ml}$ using DMSO as a 
solvent, which not effected in the growth of microbes. Mueller Hinton agar and Sabouraud dextrose agar were used as culture media for antibacterial and antifungal activity respectively. The results of the antimicrobial activity are shown in Table (1).

The screening results indicate that the activity of compounds increases with an increase in the concentration of the solutions. The synthesized compound $\mathbf{1}$ show high activity against E.coli and Streptococcus spp additionally, the compound 1 also exhibit high biological activity against all tested fungi. Whereas the compound 2 show relatively

a good activity against E.coli and all fungi. On the other hand, the compound 3 also show a good biological activity against E.coli and high antifungal activity against the Candida tropicalis, and Aspergillus niger, Table 1.

Concerning to these findings, the possible explanations of our results attribute to the fact that different antibiotics, chemical compounds and drugs have different modes of action, owing to the nature of their structure and degree of attraction to certain objective sites within bacterial and fungi cells walls and membranes.

Table 1: Microbial activities of the Schiff-base derivatives of sulphonamide drug

\section{Diameter of inhibition zone in $\mathrm{mm}$ for different microbial species}

\section{Acknowledgements}

We thank Miss A. Friemel of Chemistry Department, University of Konstanz, Germany for the NMR experiments. We are also grateful to the Departments of Physiology and Microbiology, College of Veterinary Medicine, Basrah University, Iraq

\begin{tabular}{|c|c|c|c|c|c|c|c|c|c|c|c|}
\hline \multirow[t]{2}{*}{ Microorganism } & \multicolumn{3}{|c|}{ Compound 1} & \multicolumn{3}{|c|}{ Compound 2} & \multicolumn{3}{|c|}{ Compound 3} & \multicolumn{2}{|c|}{ Standard } \\
\hline & $\begin{array}{c}200 \\
\mu \mathrm{g} / \mathrm{ml}\end{array}$ & $\begin{array}{c}100 \\
\mu \mathrm{g} / \mathrm{ml}\end{array}$ & $\begin{array}{c}50 \\
\mu \mathrm{g} / \mathrm{ml}\end{array}$ & $\begin{array}{c}200 \\
\mu \mathrm{g} / \mathrm{ml}\end{array}$ & $\begin{array}{c}100 \\
\mu \mathrm{g} / \mathrm{ml}\end{array}$ & $\begin{array}{c}50 \\
\mu \mathrm{g} / \mathrm{ml}\end{array}$ & $\begin{array}{c}200 \\
\mu \mathrm{g} / \mathrm{ml}\end{array}$ & $\begin{array}{c}100 \\
\mu \mathrm{g} / \mathrm{ml}\end{array}$ & $\begin{array}{c}50 \\
\mu \mathrm{g} / \mathrm{ml}\end{array}$ & $\begin{array}{l}\text { Ampicillin } \\
25 \mu \mathrm{g} / \mathrm{ml}\end{array}$ & $\begin{array}{c}\text { Nystatin } \\
25 \\
\mu \mathrm{g} / \mathrm{ml}\end{array}$ \\
\hline $\begin{array}{l}\text { Staphylococcus } \\
\text { aureus }\end{array}$ & 18 & 7 & - & 12 & 8 & 3 & 15 & 10 & 7 & 45 & - \\
\hline Bacillus subtillus & 15 & 11 & 8 & 15 & - & - & - & - & - & 30 & - \\
\hline Streptococcus spp. & 18 & 13 & 11 & 15 & 14 & 8 & 20 & 18 & 13 & 20 & - \\
\hline Escherichia coli & 22 & 18 & 15 & 25 & 19 & 14 & 25 & 23 & 20 & 20 & - \\
\hline $\begin{array}{l}\text { Klebsiella } \\
\text { pneumonia }\end{array}$ & 11 & 9 & - & 15 & 11 & 7 & 11 & 10 & 8 & 15 & - \\
\hline Aspergillus niger & - & - & - & 15 & 10 & 4 & 25 & 23 & 18 & - & 15 \\
\hline $\begin{array}{l}\text { Aspergillus } \\
\text { fumigatus }\end{array}$ & 18 & 15 & 11 & 25 & 15 & 7 & & & - & - & 13 \\
\hline Candida albicans & 20 & 18 & 15 & 22 & 14 & 10 & - & - & - & - & 15 \\
\hline Candida tropicalis & 13 & 9 & - & 20 & 18 & 15 & 21 & 19 & 16 & - & 11 \\
\hline
\end{tabular}

for providing the facilities

\section{REFERENCES}

[1] Henry, R.J. Bacteriological reviews, 1943, 7 (4): 175-262.

[2] Levy and Stuart, B.The antibiotic paradox : how the misuse of antibiotics destroys their curative powers(2ed.) 2002, Cambridge, Mass.: Perseus Publ. p. 51.

[3] Baluja, S.; Solanki, A. and kachhadia, N. Journal of Iranian chem. Soc.2006, 3(4), 312-317.

[4] Gupta, M.K.; Singh, H.L.;Varshney S. and VareshnyA. K.Bio inorganic chemistry and Application.2003,1(3-4), 309-320.

[5] Shivakumar, K.; Shashidhar, P.; Vithalreddy; Halli, M. Journal of Coordination Chemistry,2008, 61(14): 2274 2287.

[6] Shi, L.; Mao, W. J.; Yang, Y.; Zhu, H. L.Journal of Coordination Chemistry.2009, 62(21),3471-3477.

[7] Gupta, K. C. and Sutar,A. K. Coordination Chemistry Reviews. 2008, 252, No. 12-14,1420-1450. 
[8] Hahn, R.C.; Moratoconciecao, Y.T.; Santos, N.L.; Ferreira, J. F.; Hamdan, J. S.Mycoses. 2003, 46, 342-347.

[9] Alhassan, M.;Chohan Z.; Scozzafava, A. and Supuran, C. J. Enzyme Inhibition and Medicinal Chemistry. 2004, 19(3):263-267.

[10] Hadi, J. S. and Althahabi, N. K. Res J Pharm BiolChem Sci. 2014, 5(3), 856-866.

[11] Tella, A. C. and Obaleye, J. A.Orbital. 2010, 2(1):11-26.

[12] Shah,S. N; Basser, M. A. Asian Journal of Pharmaceutical and Clinical Research.2012,5, 3,146-149.

[13] Zhan, P.; Liu, X.; Li, Z.; Fang, Z.;Pannecouque, C.; De Clercq, E.Chem. Biodivers.2010, 7,1717-1727.

[14] Onuffer, J. J.; Ton, B. T.; Kleent, I.; Kirsch, J. F. Protein Sci.1995, 4, 1743-1749.

[15] Seeliger, S.; de Groot,B. L. J. Computer-Aided Mol. Design. 2010, 24, 417-422. 